\title{
Enacting Critical Citizenship: An Intersectional Approach to Global Citizenship Education
}

\author{
Maayke de Vries $(D)$ \\ Institute of Education, University College London, London WC1H 0AL, UK; maayke.vries.19@ucl.ac.uk
}

Received: 21 October 2020; Accepted: 18 November 2020; Published: 26 November 2020

check for updates

\begin{abstract}
Global citizenship is a popular concept that was fully embraced by UNESCO in 2015 with a framework for Global Citizenship Education (GCE). This pedagogical guidance can be characterized as transformative since it aims to foster reflective citizens who contribute to building a more inclusive, just, and peaceful world. Thus, GCE allows educators to take a critical approach to their teaching, hereby articulating a clear social justice orientation towards citizenship education. However, recent studies indicate that most interpretations and thus implementations of GCE do not translate into a social action approach. Therefore, this article conceptualizes an intersectional approach to GCE, to make a critical approach of GCE more likely by practitioners. Intersectionality was developed by Black feminists in the US, to highlight structural oppressions and privileges on the basis of analytical categories. Intersectionality, furthermore, allows for opportunities to recognize resilience and resistance in marginalized communities. Therefore, an intersectional approach to GCE would develop sensibilities among students to understand global structures of oppression and domination on the basis of analytical categories like race, gender, and class. This knowledge would lead to an awareness of one's own complicity and shared responsibility, resulting in deliberations and eventually political actions. The overall aim is to provide practitioners with a concrete suggestion of a critical interpretation of GCE, to show its potential as a social justice-orientated framework for educators in especially continental Europe.
\end{abstract}

Keywords: intersectionality; global citizenship; critical pedagogy; transformative learning; civic education; social justice

\section{Introduction}

"I began by saying that one of the paradoxes of education was that precisely at the point when you begin to develop a conscience, you must find yourself at war with your society. It is your responsibility to change society if you think of yourself as an educated person."

James Baldwin [1]

In a democracy, citizenship education is crucial, since this form of governance depends on active participation of its citizens and their ability to access and evaluate information, while overcoming inevitable disagreements. As articulated in the quote by James Baldwin, set during the civil rights movement in the United States (US), the collective of citizens should aim to strive for a fair and just society, which might mean to critique and organize against injustices carried out by the government. This primarily applies to citizens on a state level, however, the concept of global citizenship gained popularity due to the interconnectedness of our daily lives and interdependency of our actions. In 2015, UNESCO devised a framework of Global Citizenship Education (GCE), which sets out its aims and learning objectives. It is a guideline that proposes a social justice-orientation to citizenship 
education, aiming to empower students by encouraging them to take action. However, such a social justice-oriented GCE is largely absent in European classrooms at the moment [2,3]. The lack of a critical interpretation of GCE can be considered especially worrisome because of the easiness in which colonial systems go unchallenged in Europe [4]. Implementing such a critical approach is of course easier said than done, as articulated by Pashby and Sund [5]: "Global issues are complex, and we need pedagogical approaches that take up rather than gloss over these complexities" (p. 80). Hence this conceptual paper proposes to include intersectionality within GCE in Europe, to ensure a social justice-orientated GCE to develop well-informed and active citizens who are willing to understand the complexity of global issues ${ }^{1}$.

The framework of GCE, developed by UNESCO in 2015 as a part of Sustainable Development Goal (SDG) four, encourages educators to take a progressive and critical approach. Their pedagogical guideline states: "[GCE] aims to be transformative, building the knowledge skills, values and attitudes that learners need to be able to contribute to a more inclusive, just and peaceful world" (p. 15). The framework clearly and explicitly encourages transformative and critical teaching, which arguably can only be achieved by a social justice-orientation towards citizenship education $[2,8]$. Unfortunately, that critical transformative element of GCE is largely absent in many European interpretations of GCE [3,9]. Thus, the framework gives educators a lot of potential to embrace social justice in their teaching, however the actual interpretation and thus implementation neglects to do so.

Recent years have unfortunately seen a need for citizens who are able to advocate for social justice in continental Europe. The region saw a rise of populist right-wing parties who became popular with a nationalistic and anti-immigration rhetoric directly attacking the foundations of those democratic and multicultural societies. As a result, democratically chosen governments have become increasingly authoritarian in a number of European countries, hereby especially targeting marginalized communities $^{2}$. The hard-fought rights of minorities seem to become debatable, and the expression of their concerns, for example the Black Lives Matter protests all over Europe, are met with hostility and skepticism ${ }^{3}$. A reason for the denial of the existence of privilege and oppression can be explained by a lack of knowledge about the difference between structural oppression versus attitudes or practices of discrimination ${ }^{4}$. Intersectional GCE attempts to address this lack of knowledge and understanding, by fully embracing the prescribed task by UNESCO to prepare citizens to build an inclusive, just, and peaceful world.

The aim of intersectional GCE is to concretize the existing framework, thereby making a critical implementation by practitioners more likely. The aim is not to formulate yet another theoretical typology of GCE. Intersectionality is an analytical framework that highlights structural oppression and privilege on the basis of analytical categories that comprise our identities, like race, gender, class, and sexual orientation [9]. These structural benefits and disadvantages can be economical, political, but also epistemological. Thus, an intersectional interpretation of the existing framework requires a

1 In this paper, social justice references to the interpretations by Tyson and Park [6] and Bell [7], who both heavily draw on the work by Iris Marion Young, as such social justice can be explained as the elimination of injustices in distribution of resources as well as in participation and inclusion in the processes of everyday life. Thus, a social justice-orientation on citizenship education acknowledges the reality of injustices by focusing on oppression and domination, hereby highlighting the ideological, historical, and institutional foundation of these power imbalances.

2 BBC. Europe and right-wing nationalism: A country-by-country guide. Available online: https:/www.bbc.com/news/worldeurope-36130006 (accessed on 11 August 2020).

3 For example, the treatment of Roma people in Hungarian government of prime-minister Viktor Orban and the attack on women's rights in Poland under the administration of President Andrzej Dunda.

4 An example is a debate organized in the Netherlands by the Dutch Public Broadcasting (NPO) in which different stakeholders were debating on live television the statement whether or not the current debate about racism created a polarization in society. Organizations from Black communities organized a parallel session, as they made the point that racism was not something to debate about but to deliberately converse on. Lilith magazine. Nederland, We moeten het hebben over Racisme. Available online: https://www.lilithmag.nl/blog/2020/7/10/nederland-we-moeten-het-hebben-over-racisme (accessed on 11 August 2020). 
focus on structural injustices based on domination and oppression, hereby progressing from anecdotal or incidental attitudes of discrimination.

This paper then suggests the inclusion of intersectionality in the interpretation and implementation of GCE in Europe. The focus is specifically on Europe, as the suggested incorporation of intersectionality does not attempt to be universal, but highly relevant in the current reality of this region. I write this paper as a white cis-gender woman, who works as a teacher in secondary education. I continue to reflect on my own positionality in society namely one of hyperprivileged, while learning, thinking, implementing, and writing about social justice education. Hancock and Warren [10] emphasized this need for white women in education to critically examine their complications, as despite good intention we often perpetuate racist structures especially by working within neoliberal institutions. As the implementation of intersectionality obliges practitioners to examine structural inequities on the basis of race, gender, and class, a critical self-examination and reflection is prerequisite. This conceptual paper has the following structure: First the phenomena of GCE is outlined with a focus on postcolonial critique; thereafter intersectionality is thoroughly introduced, leading to the concrete inclusion of the concept in the GCE framework; lastly, some questions are posed in order to encourage a thinking towards the rethinking of analytical categories that define our identities.

\section{Global Citizenship Education}

Global Citizenship Education (GCE) is a part of a wider movement that supports the inclusion of global perspectives in national curricula. The call for teaching an understanding of human interconnectedness can be localized in Europe after the end of World War II. This development can be captured with the broad term of Global Education (GE): It was born out of a desire of western countries to educate their citizens about the rest of the world, to foster a sense of communality, and promotion of peace [11]. During the Cold War, the world was ideologically divided, hence this development was mainly located in western Europe and North America. Another influence on GE came from Development Education (DE), which was created to establish a relationship between the global north and the global south to promote 'progress' by providing aid to so-called third world countries [11]. Nowadays, DE attempts to transform itself by shying away from such a neocolonial endeavor. Nevertheless, DE did ensure a social justice orientation within the emergence of GE that is perceivable in GCE.

GCE attempts to create social change by developing citizens who understand that local issues are globally connected and vice versa. In 2012, GCE became officially a policy of the United Nations (UN) when the Global Education First Initiative (GEFI) was launched by the secretary general Ban Ki-Moon [12]. In 2015, the UN incorporated GCE in SDG four, to further acknowledge the role of citizenship education in positively influencing current global issues, like climate change and the growing inequality. Hence, the framework set out by UNESCO [13] aims for social justice on a local and global level. The pedagogy that GCE promotes is perceived to be inspired by Paolo Freire, due to the explicit focus on structures that create and maintain inequality locally as well globally along with a strong desire to take action [12]. In short, GCE is officially acknowledged by the UN as a policy in 2015, which aims to develop global citizens who challenge current-day inequities and take action to solve global issues.

Nevertheless, there is a lot of criticism on GCE, ranging from its potential exploitation by the global elite to promoting neocolonialism in disguise. These critiques resulted in a classification of contrasting approaches to GCE, which highlights the contradictions in this discipline. These multitude of interpretations are categorized in three archetypes by Pashby et al. [9]: Liberal, neoliberal, and critical. An interpretation that truly attempts to transform exploitative structures can be considered critical and thus a Freirean interpretation, while others leave the status-quo in place or even advocating in favor of it. Additionally, Pashby et al. introduced a fourth suggestion, namely postcritical, which emerged out of necessity to challenge confined thinking due to over-socialization with the current system. 
However, critical interpretations of GCE are often not that critical at all and keep current hegemonies in place. Pashby et al. [9] concluded that these so-called critical approaches "retain a strong interface with liberal orientations either explicitly or implicitly, including some with neoliberal-liberal interfaces" (p. 10). Tarozzi and Inguaggiato [3] came to a similar conclusion when examining the application of GCE in teacher training programs in several countries in Europe, where elements of critical thinking and reflection took place but without challenging taken-for-granted ideas about progress and modernization. Therefore, Stein [14] claimed that interpretations of GCE cannot be considered critical if they fail to denounce western beliefs and knowledge as universal. Hence, for an interpretation of GCE to be truly considered critical, solely focusing on some elements of Freirean pedagogy, like reflection and critical thinking, is not sufficient, and it should be combined with challenging western epistemological hegemony to influence ideas about economics and politics.

Therefore, a critical approach to GCE includes an intervention regarding ways of knowing and beliefs systems. Pashby et al. [9] suggested three of such interventions based on their extensive review of several typologies of GCE: On a methodological, epistemological, and ontological level. As their suggested interventions target postcolonial and decolonial criticism, it is worth elaborating on the latter two. The overall aim of their recommendations is to encourage a reflection on complicity and a push to rethink the current global system. Epistemological questions would address responsibility and impact, as to avoid a neoliberal application of GCE. Ontological questions furthermore challenge ideas about modernity and development. The integration of those concerns would lead towards a postcritical implementation of GCE. This paper attempts to clearly concretize a critical interpretation of GCE by integrating intersectionality on an epistemological and pedagogical level into the existing framework.

\section{Towards a Critical Interpretation of Global Citizenship Education}

Thus, a critical approach to GCE, firstly, should examine diverse ways of knowing and belief systems from Indigenous and subaltern groups. According to Zembylas [14], a critical pedagogy addressing postcolonial and decolonial critique would mean two things: A clear consultation of theory that presents non-European perspectives, and, secondly, a curriculum that presents non-European epistemologies by centralizing the histories and experiences of colonized people, also known as a counter-narratives. Stein [15] captured this as "being taught by difference", namely to unlearn the desire for universalities and to truly open up to a multitude of knowledge systems, hereby embracing the not-yet-known (p. 73). However, solely questioning, challenging, and incorporating a diverse set of knowledge systems is not enough for a critical approach towards GCE. It should also include a call for redistributions of resources and fair representation [9].

Thus, an implementation of a critical GCE would also include a call to action. In an influential article, Tuck and Yang [16] expressed very clearly that decolonization is about reparation of land and recognition of how land has a different relationship with Indigenous people. Often critical pedagogies claim to be decolonizing, but fail to address the issue of stolen land and the detrimental consequences for Indigenous people who lived and are still living there. Zembylas [14] emphasized the need for action when it comes to a decolonized critical pedagogy in the form of implicit activism, which are small-scale actions to show solidarity. Furthermore, Zembylas mentioned how a decolonizing critical pedagogy is action-orientated and promotes solidarity to heal the horrible conditions created by colonialism [14]. Hereby it becomes apparent that for a pedagogy to be considered critical and meeting the concerns of postcolonialism and decoloniality, solidarity can be shown by taking action [17]. This shows the challenge for educators to truly implement GCE as critical pedagogy, as it should not only challenge existing epistemological hegemony, but also encourage action.

Fortunately, this action-orientated approach towards citizenship education is elaborated on and realized in the US. James Banks can be perceived as a pioneer in this regard, as he was one of the first to point out that citizenship education was presenting a master narrative about society that benefitted the dominant group while oppressing minorities. Banks indicated four subsequent stages in the process towards equitable citizenship education. In the last phase, the social action approach, the curriculum 
represents citizens from all groups in society and encourages students to take action in order to solve social issues regarding equity [18]. The goal of this social action approach in citizenship education is to:

"Empower students and help them acquire political efficacy [italics as in original], the school must help them become reflective social critics and skilled participants in social change. [... ] A major goal of the social action approach is to help students acquire the knowledge, values, and skills they need to participate in social change so that marginalized and excluded racial, ethnic, and cultural groups can become full participants in US society and the national will move closer to attaining its democratic ideal" (p. 245).

This approach to citizenship education comes with a clear disposition, namely that social action is imperative for an equitable society. This in contrast to continental Europe, where a politicized citizenship education is uncommon, hence systematic exclusion on the basis of race, gender, or religion goes undiscussed and unchallenged [2]. However, these are exactly the global structures of oppression and domination that the UN targets in their framework of GCE. Intersectionality, as an analytical framework, exposes these structural inequalities by affirming counter-narratives, while aiming to challenge the status-quo on the basis of these insights. Hence the incorporation of intersectionality within GCE in Europe might address much of the abovementioned criticism by embracing counter-narratives and advocating social action to create a more equitable society.

\section{A Brief History of Intersectionality}

There is some debate about the useful and uselessness of intersectionality as an analytic framework, methodology, or disposition. This section briefly provides an overview of these debates with a focus on important elements for GCE. Intersectionality in its essence is a way to capture the "multidimensionality of marginalized subjects' lived experiences" [2,19]. There are a number of ways in which intersectionality can be used in research and practice: Namely, by applying it as an analytical framework, or as a theoretical and methodological paradigm, and lastly for political interventions [20]. This research engages with the first option, thus applying an intersectional frame of analysis to understand the impact of power structures on a local and global level. While doing so, this paper wants to adhere to the guidelines set by Moradi and Grzanka [21] in using intersectionality responsibly.

Responsible stewardship of intersectionality means that the application of intersectionality in a new context is accompanied with acknowledgments of its roots in activism before any academic engagement [21]. The term intersectionality was famously 'coined' by Kimberlé Crenshaw in 1989, however the practice of examining the interconnectedness of systems of oppressions was already done before it was capture in academic language. Already during the civil rights movement in the US in 1960s and 1970s, there was a clear understanding among women of color that they experienced a multitude of oppressions [22]. Thus Black women, Chicanas, Asian-American, and Native women developed sensibilities that captured the multitude of their oppressions [22]. Some examples of the earliest writings that expressed intersectional analyses was a pamphlet by Frances Beal in 1969, an anthology by Toni Cade Bambara in 1970, and a declaration from a collective of women naming themselves the Combahee River Collective in 1974 [22] $]^{5}$. These writings were grounded in activism, as the women were taking to the streets to improve their situation and those of others.

Throughout the 1980s, Black scholars and scholars of color described the existence of interconnectedness of systems of oppression in academic publications. This paper focusses on those scholars that inform pedagogical interpretations. Therefore, the first scholar who applied such an intersectional framework

5 The Combahee River Collective named itself after a raid led by Harriet Tubman during the Civil War, through which 750 enslaved people were liberated in South Carolina. Taylor, K. Until Black Women are Free None of Us Will be Free. The New Yorker. 2020. Available online: https://www.newyorker.com/news/our-columnists/until-black-women-are-freenone-of-us-will-be-free (accessed on 13 August 2020). 
was bell hooks, when she published in 1982 the book "Ain't I a Women" ${ }^{6}$. The book discussed how racism and sexism were simultaneously oppressive to her as a Black woman:

"From the onset of my involvement with the women's movement I was disturbed by the white women's liberationists insistence that race and sex where two separate issues. My life experience has shown me that the two issues are inseparable, that at the moment of my birth, two factors determined my destiny, my having been born black and my having been born female" ([23], p. 12).

In this quote, hooks articulated her own lived experiences as a Black woman, for whom race and gender both played a determinative role in her life. The same experience is described by Chicana and queer scholar Gloria Anzaldúa in 1987, in the book “Borderlands/La Frontara". Anzaldúa [24] touches upon intersectionality by relating it to her lived experiences as a Chicana and queer feminist:

"Women does not feel safe when her own culture, and white culture, are critical of her; when the male of all races hunt her as prey.

Alienated from her mother culture, 'alien' in the dominant culture, the woman of color does not feel safe within the inner life of her Self" (p. 20).

Intersectionality focusses on oppression and injustices, like Anzaldúa did by showing how Chicanas are looked down upon by white Americans and by men within their own community. This is a crucial element of intersectionality: Analyzing intersecting oppressive systems by listening to lived experiences of those living on the margins.

Kimberlé Crenshaw, moreover, complemented the literary work with legal evidence from court cases that showed how the law did not recognize the existence of multiple oppressions. As founder and leader scholar of Critical Race Theory (CRT), Crenshaw wanted to address the shortcomings of the civil rights discourse for people of color and show the continued oppression in the US [25]. As such, Crenshaw wrote a groundbreaking article in 1989 that 'coined' the term intersectionality by showing with legal cases how Black women faced a multitude of oppressions. In these court cases, the discrimination of Black women was perceived from a single-axis, namely either race or gender, even though they were negatively affected by both [26]. Of course, Crenshaw has written and done much since her groundbreaking article in 1989, which should not go unnoticed.

In subsequent articles, Crenshaw elaborated on her earlier work by indicating how intersectionality can be used and implemented. As such, Crenshaw [25] constructed three different ways of analysis: Structural, political, and representational intersectionality. This paper suggests a focus on structural intersectionality for an implementation within GCE, to emphasis institutionalized domination rather than individual practices or attitude. Structural intersectionality analyzes the systematic oppression based on the experiences of those with intersecting categories. Thus, social structures act discriminatory based on several categories, while intervention strategies only target one of the them. When analyzing structural intersectionality, the focus is on patterns of oppression and the continuation is a consequence of "one burden that interacts with preexisting vulnerabilities to create yet another dimension of disempowerment" [25] (p. 1249). Structural intersectionality is suitable to reveal the workings of power structures on a local and global level.

Another useful elaboration is the matrix of domination by Patricia Hill Collins, which encourages the examination of a wide range of intersecting oppressions. The matrix of domination concentrates on four domains of power: Structural, disciplinary, hegemonic, and interpersonal [26]. The matrix of domination is a framework that aims to broaden the analysis of power in society by opening up

6 The title of the book "Ain't I a Woman?" refers to a speech given by Sojourner Truth during a Women's Rights Convention in 1851. This speech is considered one of the earliest publications of intersectional work, as the speech addresses the power imbalance between Black and white women in the women's rights movement. The Sojourner Truth Project. Available online: https://www.thesojournertruthproject.com/. (accessed on 13 August 2020). 
the possibility to analyze oppressions based on local realities. This matrix is intended to describe and honor lived experiences, not to make causal claims or explanatory models [27]. While the unique knowledge of Black women regarding intersectionality always should be in the center, the matrix of domination encourages and allows for a wider application of the framework.

While acknowledging the historic origin of the employment and coining of intersectionality in the US, the analysis of intersecting oppressive systems has been useful in other regions as well. As Albert Memmi indicated, oppression starts with a difference, which then gets imposed a negative value and is generalized to an entire group, to eventually make that difference, with its negative valuation, a justification for aggression and hostility [28]. Thus, the employment of intersectionality is not limited to any specific region since all societies have the tendencies to impose negative values on differences, however, these differences might vary. An example is the application of intersectionality by Brah and Phoenix [29], through which they showed the importance of class along with gender and race as intersecting oppressions in British society. Therefore, regardless of the geographical location, intersectionality exposes the multitude of social structures that are burdensome for some sections of the society while benefitting others, whereby race and gender are salient differences that should not be disregarded.

\section{Doing Intersectionality}

The wide usage of the term intersectionality raised questions and concerns about the appropriateness of the expansion. According to Cho, McCall, and Crenshaw [20], there are two scenarios in which the increasing engagement with intersectionality takes place. The first one is as a centrifugal process, which means that intersectionality is adapted to other disciplines and discourses, hereby intersectionality conforms to methodological standards and practices of that field. A second option is a centripetal process, which means that intersectionality manages to stay closely connected to its origin and the expansion happens at the margins of the designated discipline. Intersectional GCE can be considered as an attempt for a centripetal expansion of intersectionality, since the incorporation of Black feminist pedagogy can be considered unfamiliar and provocative in the field of citizenship and GE.

Furthermore, McCall [30] suggested three different methodologies enabling intersectionality as an analytical framework. These three approaches are respectively intercategorical, anticategorical, and intracategorical. Intersectional GCE ideally utilizes an intracategorical approach, since it superficially accepts the existence of analytical categories solely to expose their negative impact on people's lives. Intracategorical intersectionality seems most suitable for GCE as it starts "with a unified intersectional core-a single social group, event, or concept-and works its way outward to analytically unravel one by one the influences of gender, race, class, and so on" [30] (p. 1787). The aim of intersectionality in GCE is to show students the complexity of power structures by examining their influence in the way analytical categories interact with each other. Even though these analytical categories are only superficially accepted, as they have to be challenged based on their historical and ideological origin. Thus, intersectional GCE makes most sense from an intracategorical approach since it looks at people as an intersectional core, hereby including all categories to thoroughly understand their reality while also challenging the construction of these categories.

As intersectionality has traveled across disciplines and continents, it caused some friction regarding its meaning and intent. Firstly, in contrast to popular opinion, intersectionality is not so much about categories of identities, rather about structures of inequality. Thus intersectionality focusses on how things work rather than who people are [20]. This also partially answers concerns about which individuals are intersectional, as the transferability of the Black women's unique experiences regarding intersecting oppressions has been debated [19]. This issue revolves around the question of whether all identities can be perceived as intersectional or only marginalized identities [19]. Moradi and Grzanka [21] problematized the narrow focus on identities. They suggested to use terminology as "axes of oppression and privilege" or "dimensions of inequality" to ensure that an analysis of power structures include a wide range of people's experiences including privilege [21] (p. 506). This would make 
a critical analysis of privilege along with oppression fundamental for intersectionality. However, Cho, Crenshaw, and McCall [20] did safeguard the origin of the practice by stating that "intersectionality neither travels outside nor is unmediated by the very field of race and gender power that it interrogates" (p. 791).

As intersectionality cannot be perceived separately from its origin, it should always acknowledge the interconnectedness of race and gender. Bilge showed how white feminists, mainly in continental Europe, have tried to disregard race from the equation when it comes to intersectionality [31]. Bilge mentioned how there is a tendency to "neutralizing the critical potential of intersectionality for social justice-oriented change" [31] (p. 405). This is done in two ways, firstly by substituting the term intersectionality with diversity, which dismantles the term from its radical and transformative political aims and conforms it to neoliberal desires [22]. This is what Bilge named "ornamental intersectionality", which leaves the status quo in place as it does not address power structures, nor aims to address sustained injustices [31]. A second way to undo intersectionality is by containing the term in academic debates. Bilge [31] claimed that disciplinary feminism tends to make the discussion about intersectionality overly academic, which keeps the focus on what intersectionality is rather than what the actual implementation looks like.

Lastly, the connection between intersectionality and social justice activism is paramount. As May [32] described, intersectionality "is political, philosophical, and pedagogical in nature: it invites us to think from "both/and" spaces and to seek justice in crosscutting ways by identifying and addressing the (often hidden) workings of privilege and oppression" (p. 21). Thus, intersectionality aims to translate the knowledge derived from the analyses into an action that disrupts the oppressive structures. Moradi and Grzanka [21] suggested that activism can be uncovering unrepresented voices and studying their resistance, community-based activist projects, or the teaching of advocacy skills (p. 509). These are all ways in which the social action that intersectionality advocates for can be realized in the classroom.

To conclude, in order to define something, it can be useful to look at what it is not. Intersectional GCE should not solely be about identities, but the examination of analytical categories should scrutinize the organization of power in society. Furthermore, intersectionality is perfectly adaptable to different contexts, however salient categories as race and gender should not be ignored. Lastly, intersectionality is not only an analytical framework, it includes a firm call to social action.

\section{Nimbly Proposing Intersectional Global Citizenship Education}

A good understanding of the history and origin of intersectionality helps to devise a possible implementation within GCE, which is the focus of this section. In order to do so, important characteristics of intersectionality will be related to the GCE framework as it was developed by UNESCO (2015), thereafter groundwork will be discussed that is essential for any pedagogy based on CRT. A large part of this section will show how intersectionality concretizes GCE in order to make a critical application feasible for practitioners. The overall aim of intersectional GCE would be to expose and examine the global interconnectedness of systems of oppression based on contextualized analytical categories.

The link between intersectionality and GCE is unequivocal on the basis of Paulo Freire's work. UNESCO (2015) takes inspiration from Paulo Freire's seminal work "Pedagogy of the Oppressed"; their framework aspires to be transformative by encouraging reflections based upon examinations of power structures eventually leading to action. Hill Collins and Bilge [22] explicitly labeled Freire's work as intersectional, since the oppressed can include everyone whose experience is determined by experiencing intersecting oppressions on the bases of class, race, ethnicity, age, religion, and citizenship. Furthermore, Hill Collins and Bilge [22] explicitly linked Freire's pedagogy with intersectionality, for the reason that students develop conscientização through dialogues of differences, aiming to produce knowledge that empowers the personal and collective. Intersectionality as well aims to empower by negotiating differences in order to build coalitions out of consensus and contestation. This, according Hill Collins and Bilge [22], then should be an important element of citizenship education: Providing students with structures through which they can share ideas and work through their 
differences for the benefit of the common good. Thus, intersectionality and GCE are essentially already linked, but this can be made more obvious.

In its core, GCE is about unifying within diversity on a local and global level; in order to make this sensible, three domains of learning were created: Knowledge, attitudes, and action. The cognitive domain focusses on the acquisition of knowledge and skills, the socio-emotional domain is about developing attitudes and values related to citizenship, while the behavioral domain defines acts that can be expected of citizens. Figure 1 shows the by UNESCO developed learning outcomes and topics.

\begin{tabular}{|c|c|c|}
\hline \multicolumn{3}{|c|}{ Domains of Learning } \\
\hline Cognitive & Socio-Emotional & Behavioral \\
\hline \multicolumn{3}{|c|}{ Key Learning Outcomes } \\
\hline $\begin{array}{l}\text { Learners acquire knowledge } \\
\text { and understanding of local, } \\
\text { national and global issues and } \\
\text { the interconnectedness and } \\
\text { interdependency of different } \\
\text { countries and populations } \\
\text { - Learners develop skills for } \\
\text { critical thinking and analysis }\end{array}$ & $\begin{array}{l}\text { - Learners experience a sense of } \\
\text { belonging to a common } \\
\text { humanity, sharing values and } \\
\text { responsibilities, based on } \\
\text { human rights } \\
\text { - Learners develop attitudes of } \\
\text { empathy, solidarity and } \\
\text { respect for differences and } \\
\text { diversity }\end{array}$ & $\begin{array}{l}\text { Learners act effectively and } \\
\text { responsibly at local, national } \\
\text { and global levels for a more } \\
\text { peaceful and sustainable world } \\
\text { - Learners develop motivation } \\
\text { and willingness to take } \\
\text { necessary actions }\end{array}$ \\
\hline \multicolumn{3}{|c|}{ Learner Attributes } \\
\hline $\begin{array}{c}\text { Informed and Critically } \\
\text { Literate }\end{array}$ & $\begin{array}{l}\text { Socially connected and } \\
\text { respectful of diversity }\end{array}$ & $\begin{array}{c}\text { Ethically responsible and } \\
\text { engaged }\end{array}$ \\
\hline $\begin{array}{l}\text { Know about local, national } \\
\text { and global issues, } \\
\text { governance systems and } \\
\text { structures } \\
\text { - Understand the } \\
\text { interdependence and } \\
\text { connections of global and } \\
\text { local concerns } \\
\text { Develop skills for critical } \\
\text { inquiry and analysis }\end{array}$ & $\begin{array}{l}\text { - Cultivate and manage } \\
\text { identities, relationships and } \\
\text { feeling of belongingness } \\
\text { - Share values and } \\
\text { responsibilities based on } \\
\text { human rights } \\
\text { - Develop attitudes to } \\
\text { appreciate and respect } \\
\text { differences and diversity }\end{array}$ & $\begin{array}{l}\text { - Enact appropriate skills, } \\
\text { values, beliefs and attitudes } \\
\text { - Demonstrate personal and } \\
\text { social responsibility for a } \\
\text { peaceful and sustainable } \\
\text { world } \\
\text { - Develop motivation and } \\
\text { willingness to care for the } \\
\text { common good }\end{array}$ \\
\hline \multicolumn{3}{|c|}{ Topics } \\
\hline $\begin{array}{ll}\text { 1. Local, national and global } \\
\text { systems and structures } \\
\text { 2. Issues affecting interaction } \\
\text { and connectedness of } \\
\text { communities at local, } \\
\text { national and global levels } \\
\text { 3. Underlying assumptions } \\
\text { and power dynamics }\end{array}$ & $\begin{array}{l}\text { 4. Different levels of identity } \\
\text { 5. Different communities people } \\
\text { belong to and how these are } \\
\text { connected } \\
\text { 6. Difference and respect for } \\
\text { diversity }\end{array}$ & $\begin{array}{l}\text { 7. Actions that can be taken } \\
\text { individually and collectively } \\
\text { 8. Ethically responsible } \\
\text { behaviour } \\
\text { 9. Getting engaged and taking } \\
\text { action }\end{array}$ \\
\hline
\end{tabular}

Figure 1. Copy of the framework by UNESCO [13].

The guideline provided by UNESCO gives a sense of direction for policymakers and educators regarding the intention and aim of GCE. The guidance can be considered quite vague, hence such various interpretations of GCE exist. By incorporating intersectionality within this framework, the outcomes, topics, and attitudes can be made more concrete and possible to live up to its transformative potential.

\subsection{The Importance of Culturally Relevant Education for Any Critical Pedagogy}

Before conceptualizing the concrete interpretation of intersectional GCE, foundational elements of such a pedagogy need to be addressed since it requires sociopolitical consciousness and critical reflections of practitioners. Intersectionality, as an academic term, is derived from CRT, as is Culturally Relevant Education (CRE). This approach to teaching and learning promotes students' cultural background to be acknowledged at school, as a way to negate covert racist practices in education. Ladson-Billings [33] formulated a clear definition of such pedagogy with three pillars: (1) Academic success; (2) cultural competence; (3) critical consciousness. CRE puts at the center that our systems of beliefs, values, standards, and worldviews determine how we think, believe, and communicate. Education, both learning and 
teaching, is influenced by these dynamics, and therefore can never be considered culturally neutral [34] $]^{7}$. Hence practitioners need to engage is a critical self-reflection to understand how these structures affect learning and teaching in their context. Similar dispositions are necessary for intersectional GCE, since it is based on the principle that dominant groups in society oppress those living on the margins, which includes through knowledge institutions like schools and universities.

It is, therefore, important to highlight that intersectional GCE cannot be considered neutral. Ross [35] explained clearly that the idea of neutrality in education is an illusion. Neutrality, Ross argued, is not objectivity; it can also indicate an ignorance of the issue. The aim of intersectionality is to advocate for social change by dismantling oppressive structures that cause inequality. This means that the current society is perceived as in need of restructuring. Freire [36] articulated this idea that the aim of education is for people to liberate themselves from the oppressive status quo. Structures that currently create and uphold inequalities in continental Europe can arguably be summarized in three interconnected systems on a local and global level: White supremacy, capitalism, and patriarchy [37]. These are the power structures in society that students are interacting with on a daily basis, which Ladson-Billings [38] called "the hidden curriculum" (p. 4). Without a critical application of GCE, the official curriculum taught at schools will only reinforce the hidden societal curriculum. Hence, one can argue that any critical approach to GCE needs to challenge those hidden power structures.

In order to do so, practitioners have to develop their sociocultural consciousness. This means to acknowledge that not all differences are equal, as some differences provide power and status in society. These critical explorations and reflections are necessary to make educators realize how their understanding of the world is shaped by their social and cultural group. Thus, their experience of the world is not the same as for people who differ on the basis of race, ethnicity, gender, social class, and language [39]. Intersectional GCE explicitly focusses on sensitive topics, like racism, sexism, and classism in order to challenge the current hegemonies. Therefore, educators have to be aware of their own privileges and complicity in a such a world order. Research has shown the importance of teachers' awareness about their own identities and beliefs when teaching sensitive and/or controversial topics [40]. Thus, when approaching GCE from an intersectional framework, the way in which the educator reflected on their positionality is detrimental for the eventual delivery.

Furthermore, pedagogy is not only about the context or content, but also includes the method of teaching. When preparing students to be active and engaged citizens, it is important not to enforce a dominator model of education. This, according to bell hooks [37], would lead to a promotion of authoritarianism along with a focus on accountability, employment, and competition. Intersectionality is about exposing structural oppression in order to challenge them, thus teaching intersectional GCE should not reinforce the oppressive structures of authoritarianism, competition, and accountability. As such, hooks advocated for "radical openness" so the exchange of ideas can take place while kindling a willingness to explore different perspectives [41]. For a compelling enactment of intersectional GCE, a community of radical openness and care is needed, hereby practitioners might make their teaching also an act of resistance.

Lastly, intersectional GCE is about resilience and transcendence, even though it examines oppression and hegemony. Transformative education aims to liberate by developing a critical consciousness. However, one needs to be wary to represent those oppressed as victims or powerless. Without "romanticizing" the experiences of those on the margins of society [19] (p. 8), intersectionality can also be observed in resilience and resistance. Gay [42] appeals educators to view intersectionality in a positive manner, without ignoring the negatives, by focusing on how marginalized people navigate through their exploitation and oppression. Hence, opportunities should be created to emphasize resistance, resilience, and transcendence in an intersectional framework of GCE.

7 There are a number of terms, Culturally Responsive Teaching or Culturally Relevant Pedagogy, used to describe an educational approach that embraces students' cultural and linguistic heritage and encourages teachers to utilize these in their teaching, in order to move away from deficit thinking about students from non-dominant cultures. 


\subsection{To Know}

The first domain, in the GCE framework designed by UNESCO (2015), is cognitive, which is perceived in this paper as the acquisition of knowledge and gaining understanding. Intersectional GCE, therefore, entails having knowledge and understanding about the economical, historical, and political structures that created categories which are beneficial for some and oppressive to others. Even though Freire [36] criticized the role of the teacher as authoritarian figures filling students with knowledge as if they were 'empty vessels', also known as the 'banking' concept of education (p. 79), he did emphasis the importance for students to be involved in the process through which knowledge is produced. As such, Freire suggested a problem-posing education, which would be a dialogue between the students' everyday experience and teachers' theoretical knowledge about the discipline [43]. Thus, knowledge and understanding, about historical, economical, and political structures, are essential for intersectional global citizenship. This knowledge would encourage students to dig below the surface and "capture the underlying forces which are at work, that these forces might now always be active or visible, that everyday experience is not always the best guide to understanding the structures that impact our lives" [44] (p. 12). Therefore, an intersectional interpretation of GCE would embrace obtaining knowledge that builds upon the everyday experience in order to develop an intersectional understanding of global citizenship.

This knowledge and understanding of the world through an intersectional lens can be considered intersectional literacy. Hill Collins and Bilge [22] interpret literacy as a much broader term, thus not only the ability to write and read, but the "skills in 'reading' the social relations of one's own experiences" (p. 162). Within GCE, intersectional literacy would mean to understand the global complexities of local issues of inequalities. Through examining the political, historical, and economical context of analytical categories and the impact of those on a local and global scale, intersectional literacy allows one to perceive inequality as a result of power dynamics on a structural level rather than a personal or individual attitude or experience. When an intracategorical intersectional pedagogy is applied, the exploration would start with a person, phenomena, or event that is examined by addressing the categories of race, gender, social economic status, sexual orientation, religion, citizenship status, and so on to understand the complexity of the injustice. In order to fully comprehend the organization of oppressive structures, the exploration needs to connect the local with the global or vice versa. Thus, intersectional literacy within GCE aims to develop the ability to look at an event or person and uncover layer for layer the weight of analytical categories on existing oppression and dominance locally as well globally.

The knowledge that is necessary for such an understanding is derived from counternarratives and lived experiences, which are considered the most important way of knowing within intersectionality. In an anecdotal excerpt, hooks [45] discusses brilliantly the value of lived experience with her students:

"I would ask them to consider whether there is any "special" knowledge to be acquired by hearing oppressed individuals speak from their experience-whether it be of victimization or resistance-that might make one want to create a privileged space for such discussion. Then we might explore ways individuals acquire knowledge about an experience they have not lived, asking ourselves what moral questions are raised when they speak for or about a reality that they do not know experientially, especially if they are speaking about an oppressed group." (p. 89)

These experiences or testimonies from oppressed groups challenge master narratives that have been well-documented, cherished, and embedded within the curriculum. Counternarratives question the master narratives that promote the status quo, since they explore the oppressive features of hegemonic assumptions about society.

Counternarratives are a way to convey knowledge, practices, and histories that have been erased from the majoritarian story. The lived experiences of marginalized people express, namely, the way discrimination works and how rights can be compromised [46]. Elenes [47] suggested testimonio as 
a practice for social justice education. The US-based Latina Feminist Group uses this tool to record stories from individuals who experienced any form of oppression. According to Elenes [47], this is a powerful tool because knowledge is produced by people who are not a part of the dominant group, thus it captures the voices from people situated on the margin of society. Counternarratives explore courage, resistance, and perseverance of oppressed groups. By actively 'listening' to those accounts, knowledge is acquired about the ways in which intersecting systems of oppression operate on a local and global level.

Besides intersectional literacy, students would benefit from having an insight into the political rights of citizens to express their concerns. An important task of citizenship education in democratic countries is arguable to provide students with knowledge about how one can enact their citizenship. For intersectional GCE, it is important that students know what political actions are possible in order the eliminate injustices [48]. These actions can be summarized as good trouble: The kind of trouble that stands up for injustices and demands a community that is at peace [49]. Hence, knowledge about the rights and responsibilities of citizens in a democracy is required to create such kind of good trouble. This could mean the ability to critically understand, assess, and utilize powerful civic terminology such as citizenship, multiperspectivity, sovereignty, self-determination, human rights, advocacy, petition, and responsibilities. A critical ontological civic posture from practitioners is required to understand the temporal influence of such concepts, herewith the role of power in the establishment of these concepts (Magill). This terminology should be contextualized, since some principles might be more applicable in one region than in others. Thus, powerful civic knowledge might give students the intellectual tools to become politically engaged.

\subsection{To Be}

The second domain in the GCE framework is the socio-emotional aspect, which focuses on attitudes and values for living in a connected and diverse world. In an intersectional approach to GCE, students move beyond appreciating differences and move towards being aware of the meaning of those differences in society. Intersectionality analyzes and critiques oppressive conditions in society, aiming to organize and strategize so they can be challenged [32]. By solely acknowledging differences without interrogating unequal power positions, the oppressive structures stay in place, allowing concepts like solidarity and empathy to remain vague and ineffective for social change [2]. Thus, intersectional literacy and powerful civic knowledge might only lead to social change when students develop awareness about complicity as an individual and responsibility within the collective.

GCE aims to be a transformative pedagogy: Guiding students on a journey to discover, re-think, and unlearn about themselves and the world. Transformative learning instigates a process in which learners construct a new and revised interpretation of an experience in the world [50]. In Freire's "Pedagogy of Oppressed" this process is referred to as concientização, explained by Torres [51] as a "dynamic process which maintains that, by rethinking our past, we can gain a fundamental understanding of the formation of our own self, the roots of our present conditions, and the limits and possibilities of being a self-in-the-world" (245). Hence, critical consciousness about oneself and the world might be required before acting upon intersectional literacy.

Critical consciousness is developed through a process of learning about oneself and the world, which aims to trigger certain emotions that lead to willingness for change. Zembylas [52] wondered what kind of emotions would instigate such change: Positive feelings like love, hope, and care, or negative perceived emotions such as guilt and shame. According to Menakem [53], discomfort can be considered a positive emotion as well as a negative one. He identified two types of pain experienced by the body as a result of discomfort. Clean and dirty pain. Clean pain is felt when there is an understanding that action is needed, but there is a lack of feeling capable to take the action or worries about the action to be taken. The experience of going through clean pain leads to improvement and growth. Dirty pain, on the other hand, is the feeling of denial, refusal, and blame, because the 
discomfort goes unaddressed out of fear. Intersectional literacy might result in an initial feeling of discomfort; however, this feeling needs to be addressed to let growth and mending be possible.

For discomfort to lead to clean pain, confrontational questions about complicity and responsibility are a prerequisite for becoming an intersectional global citizen. Zembylas [52] suggested the idea of alternative empathies, which can be described as "confrontational empathy": Sharp, incisive, and uncompromising [54] (p. 38). These alternative empathies demand that responsibility is taken for perpetuating unequal power dynamics. The goal of these alternative empathies is to challenge the discomfort by posing critical questions that lead to a realization of complicity in the suffering of others [54]. According the Zembylas [52], the realization of complicity might lead to 'implicit activism', which is: "Showing solidarity for those who suffer through modest everyday acts or standing up for those who are discriminated in the public sphere through supportive words and gestures" [14] (p. 99). These might be interpreted as the actions necessary to address clean pain, leading to growth and mending.

Of course, not everyone is contributing and benefitting equally from the existing power structures, but there is a shared responsibility to eliminate injustices within GCE. Emotions as guilt, blame, and shame, as a result of dirty pain, can be considered unproductive, as it results in defensiveness or a refusal to react. Therefore, Zembylas [17] suggested employing Iris Marion Young's social connection model of responsibility within any pedagogy that aims for transformative social justice learning. Young [55] developed this model in order to accurately describe individual responsibility within structural injustice. Young described structural injustices as systems that are kept in place by connections and relationships that are depended on each other. This corresponds with an intersectional analytical framework, in which inequalities are perceived as structural wrongdoings through a multitude of relationships in the society.

According to the social connection model of responsibility, everyone contributes to some degree to the existing structures, but not everyone bears to same responsibility. Individuals have a responsibility because "they contribute by their actions to the processes that produce unjust outcomes. Our responsibility derives from belonging together with others in a system of interdependent processes [ ... ], we bear responsibility because we are part of the process" (119). However, Young stated that not all have equal responsibility, as attainment of power and privilege to influence the processes of structural injustice are important factors in assessing the amount of responsibility. Young related the social connection model directly to global citizenship, for the reason that responsibility is not based on living in the same country but on participating in institutional process that create those structural injustices globally. Furthermore, Young mentioned that changing the structural injustice can only be done through collective action, as it contains changing institutions and processes, which is not an activity done by an individual. Hence, acting upon intersectional literacy through awareness of one's shared responsibility means engaging with politics to organize as a collective and reform the unjust structures.

\subsection{To Do}

GCE is about educating students to become citizens within nations that are globally connected. The goal of citizenship education in democratic countries can be summarized as the pursuit to make students think of solutions in ways that the common good is best served and how they can work towards that $[56,57]$. Especially in polarized societies, caused by amongst others an increase in misinformation on social media, it is important to establish first a shared understanding of an issue, which can then lead to deliberations on possible solutions. This marks the distinction between discussions and deliberations: A discussion is aimed at creating a shared understanding of a topic by listening, questioning, and researching, while deliberations are conversations that aim to work towards a solution for the formulated injustice. In an intersectional interpretation of GCE, solutions for global structures of injustices would mean a reorganization through collective political action. Thus, an intersectional GCE encourages students to develop intersectional literacy based on which an awareness can be realized 
about their shared responsibility for global structures of oppressions, eventually guiding towards deliberations on what political actions can be taken.

Nurturing citizens who are politically active in order to achieve a socially just society is an important aim of GCE. Ross [35] formulated two ways in which students can be politically engaged when attempting to achieve social justice: Political participation and intentional actions. Political participation includes voting and signing petitions, but also the utilization of freedom of expression, along with undermining the actions of the government if these contradict principles of justice. Intentional actions refer to behaviors that advocate for human connections and meaningful experiences, in order to challenge passivity, commodification, and separation. Intersectional CGE suggests translating critical consciousness about the global interconnectedness of systems of oppression into political engagement through political participation and intentional actions.

Political participation might be deliberating on possible solutions for the intersecting global injustices students have come to realize. Hess and McAvoy [56] promote discussions across differences as an essential component of democratic societies, it teaches students to weigh evidence, consider competing views, form an opinion, articulate that opinion, and respond to those who disagree. Students create a shared understanding of an issue based on which deliberations can take place. Deliberating means to think about issues in society and make decisions in order to work towards the common good [56]. Thus students behave like citizens when they deliberate on how to solve societal issues, while keeping in mind that the aim is to come up with a solution that is best for the common good [56]. By engaging students with real-life problems, "students learn to see each other as political equals and to inculcate them into the practice of reason giving and considering how their views and behaviors affect others" (6). Thus, deliberation is on the basis of well-informed research and requires reflectivity regarding the consequences of one's actions for others.

Deliberations within intersectional GCE are about sensitive and controversial issues as racism, islamophobia, and classism. Hess and McAvoy [56], therefore, clearly stated the difference between empirical questions and political ones. Empirical questions are those that can be answered with a 'right' answer through research, while political questions are those that instigate a quest into how we should life together. Settled empirical questions should not be presented as something that is up for debate because they are not. However, on the basis of a settled empirical question, a political issue might arise. A political question is one that people engage with in the public sphere by a referendum, in the courts, or other political platforms. Especially in polarized societies, it is important to understand the difference between empirical and political questions when letting students deliberate.

However, the importance of deliberation within citizenship education has been criticized because it advocates for consensus building, while for issues concerning oppression, there should be no middle ground. Tayari Jones [58] articulated this particularly well: "The middle is a point equidistant from two poles". That's it. There is nothing inherently virtuous about being neither here nor there. Buried in this is a false equivalency of ideas, what you might call the "good people on both sides" phenomenon. Therefore Gibson [59] suggested that students should understand that voices from the margins "are essential to [comprehend] the full complexity of social structures and political processes" (12). Therefore, intersectional GCE would require discussions and deliberations to fully acknowledge and incorporate counter-narratives. Lived experiences and counternarratives are paramount, as they "amplify perspectives that challenge the political status quo and that make visible how power operates within political discourse and action" [59] (p. 10). These deliberations, otherwise, risk to reproduce the social inequalities that it aims to eliminate. This happens when the influence of power on accessibility of information and decision-making procedures is neglected [59]. Therefore, counternarratives based on lived experiences should be given epistemic privilege in any deliberation that aims to solve global structures of oppression, in order to avoid 'meeting in the middle'.

These deliberations ideally lead to collective actions. Taking action can have a broad variety of meanings; including long-term commitments or quick intervention. The Democratic Knowledge Project from Harvard University helps to guide civic actions on the basis of ten questions that help to 
ensure equity, self-protection, and efficacy. The last three of these questions work towards influencing the situation through direct action, like petitions and building alliances. Carly Muetterties [34], furthermore, translates taking action in addressing stakeholders in any given situation and target those institutions or people. Taking action can therefore be a conversation outside of the classroom about such a global real-life problem, which would emulate active citizenship by advocating for issues that they deem important. Other examples of quick interventions are a public service announcement or creating a poster to raise awareness.

A long-term commitment that reflects the three domains of intersectional GCE is the practice of Youth Participatory Action Research (YPAR). According to Gibson [59], "YPAR is not just academic research; it is a way of coming to know an issue through collaboration, community, embodied knowledge, and action" (p. 13). Again, a link with Paulo Freire's work can be made: Freire promoted learners' participation in knowledge production by encouraging inquiry as a way to learn about the world and themselves [36]. Every YPAR starts with identifying the problem by listening to the community to understand the oppression, along with consulting readings, and other forms of media [12]. The involvement of the community in the knowledge production is paramount, as it centralizes voices from the margins by collecting oral histories and testimonios to explore issues of injustices. Thereafter, students create their research design by devising an action plan to answer to their research question, which then leads to the collection of data, by for example gathering and recording counternarratives, eventually initiating an appropriate action or project [36]. As such, an intersectional approach towards all three domains of learning might lead to a critical implementation of GCE. A visual summary of such an intersectional approach to GCE is presented in Figure 2.

\section{INTERSECTIONAL GLOBAL \\ CITIZENSHIP EDUCATION}
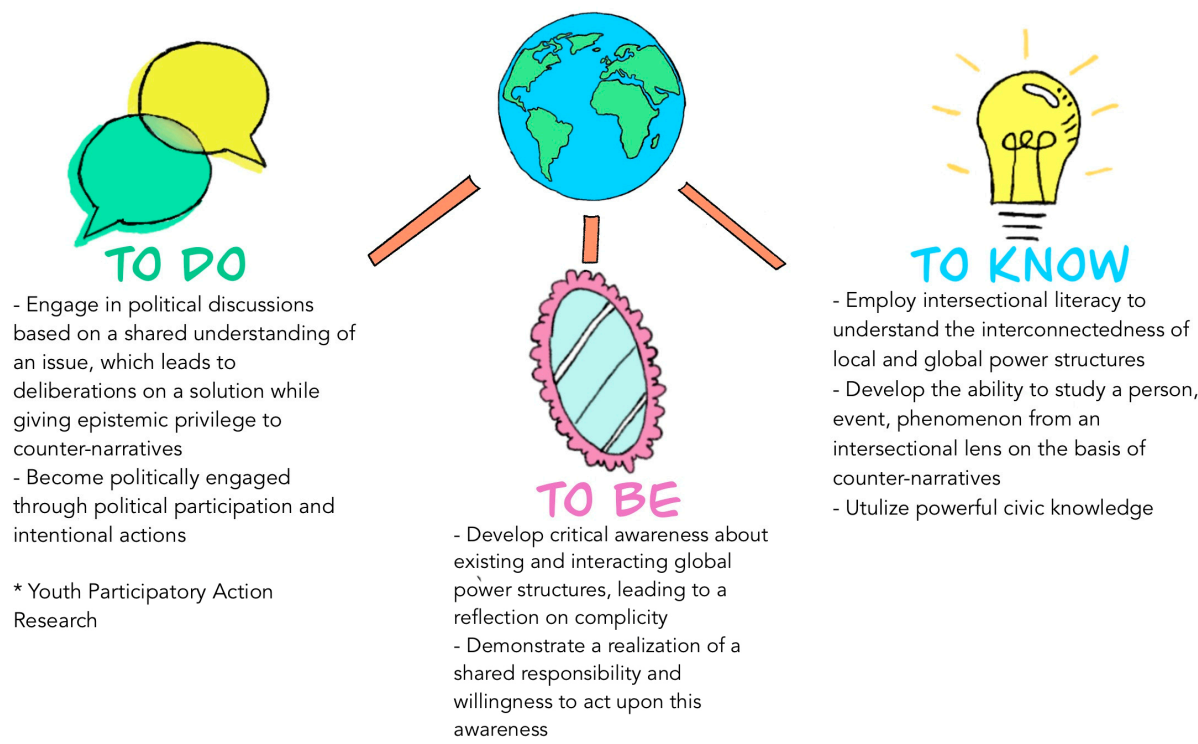

Figure 2. Visual representation of an intersectional approach to Global Citizenship Education.

The solving of structural injustices that intersectionality exposes is of course not the responsibility of students, rather students get familiar with acting as citizens who can collectively address these issues. By deliberating on issues of social injustices, students come to realize their ability to influence unjust processes through political participation and intentional actions. The actions can be performing implicit activism by discussing their insights during dinner table conversations or through explicit activism by directly addressing stakeholders. 


\section{Postcritical Global Citizenship Education}

An intersectional interpretation of GCE aspires to be a critical pedagogy, but it should be noted that to truly aim for a transformation, one should attempt to think drastically outside of the existing structures. Pashby et al. [9] emphasized that our current system, with its clear predeterminations about modernity/coloniality, hinders our imagination about 'other' possible interpretations of GCE. Andreotti has given examples of GCE orientations that suggest alternative possibilities for the world, whereby local ontologies are centralized and the focus is on unlearning and re-thinking $[4,60]$. Even though the thinking about alternatives or 'other' orientations of GCE is almost impossible when educated deeply in hegemonical western ideas, intersectionality can do an attempt to challenge pre-scribed expectations.

Intersectionality is not only a way to analyze and strategize, it can also help to rethink hegemonical structures. May [32] described intersectionality as a "resistant imaginary", since it disrupts dominant social imagination by thinking 'otherwise' through engaging with different forms of knowing and including a wide range of possible sources (p. 34). The ability of intersectionality to function as a disruptor was also expressed by bell hooks, as she mentioned the need to get away from binary thinking, which was constructed by dominator culture [37]. Hooks suggested that it might be more useful to identify ourselves on the basis of questions like "[How] am I compassionate?" or "[How] do I serve others?". Thus, intersectionality exposes categories as structural ways to oppress people, but also encourages one to critically question the power behind those categories and the initiator of these constructions.

This rethinking of identity is particularly well articulated in the work of Gloria Anzaldúa and the idea of "New Tribalism". Anzaldúa's theory regarding new tribalism is thoroughly theorized as the process of conocimiento, which is too complicated to fully address here. However, Anzaldúa's criticism on the oppressive categories is useful in order to articulate critique on the categorization of people based on race, gender, and class: "Conventional, traditional identity labels are stuck in binaries, trapped in jaulas (cages) that limit the growth of our individual and collective lives" [61] (p. 66). New Tribalism was, according to Anzaldúa, an answer to our globalized world in which we are interconnected by the exchanging of goods, ideas, and information [49]. The goal of new tribalism is to be inclusive by building bridges across continents through rejecting the categories that were invented to exploit, oppress, and divide humanity [49]. Thus, intersectional GCE should also take on the rethinking of hegemonical structures by questioning the purpose of its creation. Hooks suggested other ways of defining ourselves by looking at what one is contributing to society and how one is caring for others. Hence, intersectional GCE might want to elaborate on inquiries as, who owns these categories? Who profits from these existing structures? And what are other ways to define us?

\section{Conclusions}

This conceptual paper proposed intersectional GCE, as it deals with the criticism that is often expressed about the hidden eurocentrism and neoliberalism within GCE. The proposed inclusion of intersectionality to the GCE vocabulary aims to provide practitioners, like myself, with a concrete suggestion of a critical interpretation of GCE, hereby showing its potential as a social justice-orientated framework for educators in continental Europe. Intersectional GCE, furthermore, aims to push educational research to widely include pedagogical theorists from the margins of society, by incorporating their work in all three domains of learning. The intersectional interpretation of GCE is done on a basis of responsible stewardship through fully acknowledging the origin of the practice and concept by Black scholars and scholars of color.

Intersectional GCE intends to present a comprehensible approach to teaching the complexities of global injustices. The examination of structural elements of intersecting oppressions based on analytical categories aims to advance the explanation of inequalities based on personal attitudes or anecdotes. In order to do so, lived experiences and counternarratives are perceived as the most important form of knowledge. Hereby the aim is to develop an intersectional literacy, which provides 
students with a framework to look at the world around them and understand the complexities of inequities. The exposure of structural oppression and domination might prompt feelings of discomfort, which should be addressed to allow for growth, improvement, and mending. To avoid a feeling of inadequacy or denial, an emphasis on a shared responsibility for these global structures of injustices is more productive. Actions can then be taken on the basis of a shared understanding of the committed injustices. Deliberations are one form in which students can emulate active citizenship, whereby epistemic privilege is giving to voices from the margins. These discussions result in either implicit or explicit activism that encourage students to engage with intentional actions. Especially when authoritarianism seems to be on the rise and human rights are compromised, students need to be prepared to create good trouble.

However, intersectionality does not only allow for analyzing structural oppression and dominance on the basis of analytical categories, it also encourages us to rethink those. Rather than taking the analytical categories for granted, a GCE that aims to imagine the yet unthinkable would promote the questioning of categories such as race, gender, and class. Hence, Anzaldúa's theory of new tribalism could inform practitioners about other ways in which we ought to define ourselves. The questions proposed by bell hooks emphasized care and compassion, which might help us to redefine the concept of identity. In conclusion, this conceptual paper intended to show the potential of GCE by highlighting its social justice-orientation, hereby especially focusing on continental Europe where such an approach is largely absent.

Funding: This research received no external funding.

Acknowledgments: I would like to thank Massimiliano Tarozzi, Victoria Showunmi, and Rose Borunda for their feedback and suggestions. Furthermore, I would like to express my appreciation to Ben Kisby for support and encouragements.

Conflicts of Interest: The author declares no conflict of interest.

\section{References}

1. Baldwin, J. A talk to teachers. The Saturday Review, 21 December 1963. Available online: https://www.spps.org/ cms/lib010/MN01910242/Centricity/Domain/125/baldwin_atalktoteachers_1_2.pdf (accessed on 3 July 2020).

2. Tarozzi, M.; Torres, C. Global Citizenship Education and the Crises of Multiculturalism. Comparative Perspectives; Bloomsbury Academic: London, UK, 2016.

3. Tarozzi, M.; Inguaggiato, C. Teachers' Education in GCE: Emerging Issues in a Comparative Perspective; Springer Science and Business Media LLC.: Berlin, Germany, 2018; 164p.

4. Andreotti, V. Soft versus critical global citizenship education. In Development Education in Policy and Practice; Palgrave Macmillan: London, UK, 2006; pp. 40-51.

5. Pashby, K.; Sund, L. Decolonial options and foreclosures for global citizenship education and education for sustainable development. Nord. J. Comp. Int. Educ. 2020, 4, 66-83. [CrossRef]

6. Tyson, C.A.; Park, S.C. Civic education, social justice and critical race theory. In The SAGE Handbook of Education for Citizenship and Democracy; Arthur, J., Davies, I., Hanh, C., Eds.; SAGE Publications: London, UK, 2008; pp. 29-39. [CrossRef]

7. Bell, L.A. Theoretical foundations for social justice education. In Teaching for Diversity and Social Justice, 3rd ed.; Adams, M., Bell., L.A., Goodman, D.J., Joshi, K., Eds.; Taylor \& Francis Group, Routledge: New York, NY, USA, 2016; pp. 23-54.

8. Kiwan, D. 'Race', 'Ethnicity' and Citizenship in education: Locating intersectionality and migration for social justice. In The Palgrave International Handbook of Education for Citizenship and Social Justice; Peterson, A., Hattam, R., Zembylas, M., Eds.; Palgrave Macmillan UK: London, UK, 2016; pp. 3-25. [CrossRef]

9. Pashby, K.; da Costa, M.; Stein, S.; Andreotti, V. A meta-review of typologies of global citizenship education. Comp. Educ. 2020, 56, 144-164. [CrossRef]

10. Warren, C.A.; Stephen, D.H. Introduction. White women's work? Unpacking its meaning and significance for the contemporary schooling of diverse youth. In White Women's Work. Examining the Intersectionality of Teaching, Identity, and Race; Stephen, D.H., Chezare, A., Eds.; Information Age Publishing, Inc.: Charlotte, NC, USA, 2017. 
11. Bourn, D. The emergence of global education as a distinctive pedagogical field. In The Bloomsbury Handbook of Global Education, 1st ed.; Douglas, B., Ed.; Bloomsbury Handbooks; Bloomsbury Academic: London, UK, 2020.

12. Ramalho, T. Paulo freire: Accidental global citizen, global educator. In The Bloomsbury Handbook of Global Education, 1st ed.; Douglas, B., Ed.; Bloomsbury Academic: London, UK, 2020; pp. 52-60.

13. UNESCO. Global Citizenship Education. Topics and Learning Objectives. UNESCO, 2015. Available online: http://unesdoc.unesco.org/images/0023/002329/232993e.pdf (accessed on 12 June 2020).

14. Zembylas, M. Affect, race, and white discomfort in schooling: Decolonial strategies for 'pedagogies of discomfort'. Ethics Educ. 2018, 13, 86-104. [CrossRef]

15. Stein, S. Pluralizing possibilities for global learning in western higher education. In The Bloomsbury Handbook of Global Education, 1st ed.; Douglas, B., Ed.; Bloomsbury Academic: London, UK, 2020; pp. 63-75.

16. Tuck, E.; Wayne, Y. Decolonization is not a metaphor. Decolonization Indig. Educ. Soc. 2012, 1, 1-40.

17. Zembylas, M. Re-conceptualizing complicity in the social justice classroom: Affect, politics and anti-complicity pedagogy. Pedagog. Cult. Soc. 2020, 28, 317-331. [CrossRef]

18. Banks, J.A. Approaches to multicultural curriculum reform. In Multicultural Education. Issues and Perspectives, 7th ed.; James, A., Cherry, A., Banks, M., Eds.; John Wiley \& Sons, Inc.: Hoboken, NJ, USA; pp. $233-256$.

19. Nash, J.C. Re-thinking intersectionality. Fem. Rev. 2008, 89, 1-15. [CrossRef]

20. Cho, S.; Kimberlé, W.C.; Leslie, M. Toward a field of intersectionality studies: Theory, applications, and praxis. Signs J. Women Cult. Soc. 2013, 38, 785-810. [CrossRef]

21. Moradi, B.; Patrick, R.G. Using intersectionality responsibly: Toward critical epistemology, structural analysis, and social justice activism. J. Couns. Psychol. 2017, 64, 500-513. [CrossRef]

22. Collins, P.H.; Sirma, B. Intersectionality; Key Concepts; Polity Press: Cambridge, UK, 2016.

23. Hooks, B. Ain't I a Women. Black Women and Feminism; South End Press: Boston, MA, USA, 1982.

24. Anzaldúa, G. Borderlands. la Frontera. the New Mestiza; Aunt Lute Book Company: San Francisco, CA, USA, 1987; Volume 1.

25. Crenshaw, K. Mapping the margins: Intersectionality, identity politics, and violence against women of color. Stanf. Law Rev. 1989, 43, 1241-1299. [CrossRef]

26. Hill, C.P. Black Feminist Thought. Knowledge, Consciousness, and the Politics of Empowerment, 2nd ed.; Routledge: New York, NY, USA, 2000.

27. Collins, P.H. The difference that power makes: Intersectionality and participatory democracy. Investig. Fem. 2017, 8, 19-39. [CrossRef]

28. Memmi, A. Racism; Steve, M., Ed.; University of Minnesota Press: Minneapolis, MN, USA, 2000. Available online: http://www.jstor.org/stable/10.5749/j.ctt5vkbgd (accessed on 28 August 2020).

29. Brah, A.; Ann, P. Ain't I a woman? Revisiting intersectionality. J. Int. Women's Stud. 2004, 5, 75-86.

30. McCall, L. The complexity of intersectionality. Signs J. Women Cult. Soc. 2005, 30, 1771-1800. [CrossRef]

31. Bilge, S. Intersectionality undone: Saving intersectionality from feminist intersectionality studies. Du Bois Rev. Soc. Sci. Res. Race 2013, 10, 405-424. [CrossRef]

32. May, V.M. Contemporary sociological perspectives. In Pursuing Intersectionality, Unsettling Dominant Imaginaries; Taylor \& Francis Group, Routledge: New York, NY, USA, 2015.

33. Ladson-Billings, G. But that's just good teaching! The case for culturally relevant pedagogy. Theory Pract. 1995, 34, 159-165. [CrossRef]

34. Krutka, D.; Milton, M. Taking Action in Social Studies Inquiries with Carly Muetterties. Visions of Education. 2019. Available online: https:/visionsofed.com/2019/03/05/episode-107-taking-action-in-social-studiesinquiries-with-carly-muetterties/ (accessed on 23 July 2020).

35. Ross, E.W. Rethinking Social Stucies. Critical Pedagogy in Pursuit of Dangerous Citizenship; Critical Constructions: Studies on Education and Society; Information Age Publishing, Inc.: Charlotte, NC, USA, 2017.

36. Freire, P. Pedagogy of the Oppressed, 30th ed.; Continuum: New York, NY, USA, 2000.

37. Kamau, B.W.; Hari, K. Speaking with Bell Hooks \& Talking DACA. Politically Re-Active. Available online: https://www.topic.com/politically-re-active (accessed on 5 July 2020).

38. Ladson-Billings, G. Lies my teacher still tells. In Critical Race Theory Perspectives on the Social Studies: The Profession, Policies, and Curriculum; Information Age Publishing, Inc.: Charlotte, NC, USA, 2003; pp. 1-11.

39. Villegas, A.M.; Tamara, L. Preparing culturally responsive teachers: Rethinking the curriculum. J. Teach. Educ. 2012, 53, 20-32. [CrossRef] 
40. Ho, L.-C.; Paula, M.; Diana, H.; Brian, G. Teaching and learning about controversial issues and topics in the social studies. In The Wiley Handbook of Social Studies Research; John Wiley \& Sons, Ltd.: Hoboken, NJ, USA, 2017; pp. 319-335. [CrossRef]

41. Hooks, B. Teaching Community. A Pedagogy of Hope; Routledge: New York, NY, USA, 2003.

42. Gay, G. Culturally Responsive Teaching. Theory, Research, and Practice, 3rd ed.; Multicultural Education Series; Teachers College Press: New York, NY, USA, 2018.

43. Blackmore, C. The Opportunities and Challenges for a Critical Global Citizenship Education in One English Secondary School. Ph.D. Thesis, University of Bath, Bath, UK, 2014.

44. Wrigley, T. 'Knowledge', curriculum and social justice. Curric. J. 2018, 29, 4-24. [CrossRef]

45. Hooks, B. Teaching to Transgress. Education as the Practice of Freedom; Routledge: New York, NY, USA, 1994.

46. Adami, R. The critical potential of using counternarratives in human rights education. In Critical Human Rights, Citizenship, and Democracy Education: Entanglements and Regenerations; Michalinos, Z., André, K., Eds.; Bloomsbury Collections; Bloomsbury Academic: London, UK, 2018; pp. 67-84. [CrossRef]

47. Elenes, C.A. Nepantla, spiritual activism, new tribalism: Chicana feminist transformative pedagogies and social justice education. J. Lat. Lat. Am. Stud. 2013, 5, 132-141. [CrossRef]

48. Banks, J.A. Failed Citizenship and Transformative Civic Education. Educ. Res. 2017, 46, 366-377. [CrossRef]

49. Pérez, D.R. New tribalism and chicana/o indigeneity in the work of gloria anzaldúa. In Routledge Handbook of Chicana/o Studies; Lomelí, F., Segura, D., Benjamin-Labarthe, E., Eds.; Routledge: London, UK, 2019; pp. 242-255.

50. Taylor, E.W. Transformative learning theory. New Dir. Adult Contin. Educ. 2008, 2008, 5-15. [CrossRef]

51. Torres, C.A. 13. transformative social justice learning: The legacy of paulo freire. In Utopian Pedagogy; Mark, C., Ed.; University of Toronto Press: Toronto, ON, Canada, 2007; pp. 242-247. [CrossRef]

52. Zembylas, M. Reinventing critical pedagogy as decolonizing pedagogy: The education of empathy. Rev. Educ. Pedagog. Cult. Stud. 2018, 40, 404-421. [CrossRef]

53. Menakem, R. My Grandmother's Hands. Racialized Trauma and the Pathyway to Mending Our Hearts and Bodies; Central Recovery Press: Las Vegas, NV, USA, 2017.

54. Pedwell, C. De-colonising empathy: Thinking affect transnationally. Samyukta A J. Women Stud. 2016, 16, 27-49.

55. Young, I.M. Responsibility and global justice: A social connection model. Soc. Philos. Policy 2006, 23, 102-130. [CrossRef]

56. Hess, D.E.; Paula, M. The Political Classroom; Routledge: New York, NY, USA, 2015.

57. Abdi, A.A.; Shultz, L.; Pillay, T. Decolonizing global citizenship. In Decolonizing Global Citizenship Education; Sense Publishers: Rotterdam, The Netherlands, 2015; pp. 1-9.

58. Jones, T. There's Nothing Virtuous about Finding Common Ground. Time Magazine. 25 October 2018. Available online: https://time.com/5434381/tayari-jones-moral-middle-myth/ (accessed on 13 August 2020).

59. Gibson, M. From deliberation to counter-narration: Toward a critical pedagogy for democratic citizenship. Theory Res. Soc. Educ. 2020, 48, 431-454. [CrossRef]

60. Stein, S.; Andreotti, V. Postcolonial insights for engaging difference in educational approaches to social justice and citizenship. In The Palgrave International Handbook of Education for Citizenship and Social Justice; Andrew, P., Robert, H., Michalinos, Z., James, A., Eds.; Palgrave Macmillan UK: London, UK, 2016; pp. 229-245. [CrossRef]

61. Geographies of selves—Reimagining identity nos/otras (us/other), las nepantleras, and the new tribalism. In Light in the Dark/Luz En Lo Oscuro, Rewriting Identity, Spirituality, Reality; AnaLouise, K., Ed.; Latin America Otherwise; Duke University Press: Durham, NC, USA, 2015.

Publisher's Note: MDPI stays neutral with regard to jurisdictional claims in published maps and institutional affiliations. 